\title{
ON AN AMENDMENT OF THE MORALITY \\ OF A PHYSICIST'S PROFESSIONAL ACTIONS. \\ A NEW ELEMENT OF INCULTURATION OF CHRISTIANITY INTO A SCIENTIFIC-TECHNOLOGICAL CIVILIZATION
}

\begin{abstract}
A b s t r a c t. Physicists are bound, by the established methods and standards of Physics, to think and act within an epistemological framework that is deeply influenced by I. Kant. The epistemological climate they find themselves in is opposed to the epistemological climate of Natural Realism and, thus, to the epistemological climate of Christian revelation, when it speaks about our world. This contrast damages the internal harmony of each physicist's mental world to a degree that depends on his overall mindset as well as on his professional work. This situation is ongoing since the Scientific Revolution of the $17^{\text {th }}$ century, so that the earlier civilization imbued with a realist and Christian spirit is superseded, by and large, by a scientific-technological civilization.

The historical development of Physics has brought about the situation that the professional work of physicists produces, with its doubtless successes and contributions to progress, immediately together with its morally good object two enchained morally bad effects. The first bad effect is the co-existence, in a physicist's mind, of two opposite epistemological climates, which damages the internal harmony of his mental world. That immediately entails a second bad effect, insofar a physicist who wants to be professionally competitive finds himself obliged to follow the methods and standards of physics as they happen to be now. In that way, he contributes to the lack of harmony in his own mental world and his grain of sand to perpetuate the spirit of those methods and standards. The situation is worse for a physicist who is a Christian and wants to do his professional work for the glory of God (cf. 1 Cor 10:31). In both cases, a physicist is denying in practice, by his professional work, what he is convinced of in theory, namely of Natural Realism and, additionally in the case of a Christian, that Christian revelation speaks of our world in the spirit of Natural Realism.

All that is not unknown, but nevertheless is practically passed by in the academic discourse. Therefore, the purpose of this article is to call attention to this topic and then to suggest some ways of examining more specifically the contrast of the epistemological climates.
\end{abstract}

Dr. RUDOLF LARENZ - present address: Fredrikinkatu 41 C 39, FI - 00120 Helsinki; e-mail: rlarenz@gmail.com; ORCID: 0000-0001-5208-9869. 
As Physics is partly shaped by experimental interventions, its historical development is also partly contingent. This is why it is possible to achieve a better harmony of the epistemological climates of Physics and Natural Realism. The article suggests some ideas in that respect, too. If these ideas turn out to be fruitful, they would contribute to the inculturation of Christianity in our scientific-technological civilization. In other words, it would be a flanking aid for the New Evangelization.

Key words: inculturation of Christianity; morality of actions with double effect; physics; scientific-technological civilization; Natural Realism; Christian revelation; epistemological climates.

\section{INTRODUCTION}

In an earlier article, it has been argued that the morality of a physicist's professional activity, while assumed as morally good (disregarding abuses, structures of sin and the like), suffers from two specific negative effects immediately and almost inevitably attached to the proper professional actions. ${ }^{1}$ These negative effects stem from the strong difference, if not opposition, between the epistemological climate a physicist has grown up and the epistemological climate, which his professional work is imbued with. Some more details will be presented in section II below. As it seems, there is no publication that deals with this issue. Thence, the view presented is absolutely minoritarian, but it draws on facts that hardly can be contested (sections III, IV). The goal of the present article is to suggest the beginning of an amendment already insinuated in that earlier article (sections V, VI).

The difference between the epistemological climates referred to is within the scope of theologians as well as non-believers. The latter are, or have been, acquainted with the epistemological climate generated by Natural Realism. The former are, additionally, acquainted with the epistemological climate in which Christian revelation speaks about this world and which is fully in harmony with the epistemological climate generated by Natural Realism. Now, the epistemological climate of physics is opposed to Natural Realism and, therefore also opposed to the epistemological climate in which Christian revelation speaks about this world.

Accordingly, a first step towards the purpose of this article is to foster the awareness of this opposition, among non-believers as well as among theologians. As has just been mentioned, everybody has grown up, at least until

${ }^{1}$ Rudolf Larenz, Physics - 'Alienation from' instead of 'Orientation towards' the Creator?, Roczniki Teologii Moralnej [Lublin] 3(58), 2011: 5-37. 
a certain age, in the climate of Natural Realism. The distinctive trait is that reality itself is understood to be cognitively assimilated by a human person. This stance is opposed to ideas like language games (Wittgenstein), views of the world as-if (Vaihinger), and purely invented "cognitive" representations (Einstein). Theologians know that Christian revelation endorses Natural Realism, and non-believers know that theologians hold precisely that view. In other words, there is a common starting point, which is decisive for the dialogue between Theology and Physics to be well-founded.

Before turning to a possible amendment of the morality of a physicist's professional actions, let us summarize the assessment of its present morality as given in detail in the article quoted. Above all, it draws on the difference of "epistemological climates", one stemming from the world as experienced and given (natural realism, appreciation of the high cognitive value of experience) and the other stemming from the view of the world as construed model (appreciation of the cognitive value of experience as low or none).

\section{MORAL ASSESSMENT}

The assessment of the morality of a physicist's professional actions follows the theory of the morality of actions with double effect. First, the professional work of a physicist is supposed to produce something morally good. Or in classical terminology, the moral object of these actions is good. ${ }^{2}$ But in our case, the object is accompanied by two bad effects, namely

(i) damaging impact on the internal harmony of the physicist's mental world by hosting two opposite views: the physicist's actions are (knowingly or not) inspired by the view that nature is not intelligible, while he has grown up in the view that nature is intelligible (natural realism, and

(ii) a contribution to perpetuating that situation (i), in paticular, to perpetuating an epistemological climate opposed to natural realism.

Notice that the morally bad effects are "almost necessarily" connected with the object of the action. Properly speaking, the bad effects are not only connected with the object, or immediately subsequent to the object. Rather, the bad effects come about by realizing the very action producing its object. This yields a sort of contradiction in the physicist's mind to the degree he is (implicitly or explicitly) convinced of Natural Realism: he acts as if he had

\footnotetext{
${ }^{2}$ Cf. Catechism of the Catholic Church, n. 1751-1754.
} 
the view that nature is not intelligible, despite of knowing (implicitly or explicitly) that nature is intelligible.

These bad effects do not turn the total moral value from good into bad, but they diminish the action's moral goodness that would derive from the object alone. In this sense, the two bad effects could be qualified as a moral circumstance inseparably integrated into the professional action.

It is difficult to reject the comparison of the mentioned contradiction in a physicist's mind to a self-mutilation as being 'too strong'. In most cases, the situation that a physicist, by his daily professional actions, practically contradicts what he is theoretically convinced of, will lead to a sort of inseparable mixture of two opposite stances, in his mental world. It might happen, and it often does happen, that he is not really aware of this situation or, when being aware of it, is not aware of its cause.

This situation is self-protecting in the following sense: if a physicist wants to be professionally competitive, his professional work should obey the methods and standards of physics. Thence, he contributes nolens volens his grain of sand to perpetuate the spirit of those methods and standards. This argument holds, of course, for every profession. But there can be differences from one profession to the other regarding the degree to which the spirit of the standards is in harmony with, or opposed to, natural realism.

The fact that this particular lack of harmony within a physicist's mental world protects itself adds something to the moral assessment of his professional actions just mentioned. In my view, the moral goodness of the professional actions diminishes further, because that lack of harmony of a physicist's mental world is headed to increase over time, which in turn might bring about a deep alienation from Natural Realism. Additionally, that lack of harmony of a physicist's mental world is shared by all professionals of physics so that it can hardly be overcome by a single physicist alone.

Let us now turn to the case of a physicist who is a Christian. The appreciation of experience as having little cognitive value (or none at all), is not only opposed to Natural Realism, but also to the appreciation Christian revelation gives to the cognitive value of experience when speaking about our world. As has already been mentioned, Holy Scripture gives to understand that a natural theology is possible, i.e. that human experience and reason (= natural realism) are able to attain the insight that this world is what the Bible calls 'created'. Therefore, this world has a Creator. The all-important 
circumstance here is that this insight can be achieved unaided by the Bible or by any other knowledge of Christianity. ${ }^{3}$

Thus, if a physicist is (implicitly or explicitly) convinced that a natural theology exists, he finds himself in the situation that his daily professional activity practically contradicts not only Natural Realism that he is theoretically convinced of, but also the specific tenet of Christian revelation about the intelligibility of this world. In other words: He acts as if he had the view by reason and faith that nature is not intelligible, despite of knowing (implicitly or explicitly) that nature is intelligible. In rigor, this holds, first, only in relation to the natural knowledge of the Creator. Nevertheless, if nature discloses its innermost constitution as created, it will also disclose something, in a subordinated way, about its other properties such as its own laws ("laws of nature").

This lack of harmony might have different degrees in different persons according to two "parameters." The first parameter covers the range of worldviews: the lowest degree belongs to a physicist who is, more or less, anchored in Natural Realism, but is not a believer and as such has not committed himself to Christian revelation. A higher degree refers to a physicist who is a Christian and as such has committed himself (implicitly or explicitly) to the view of Christian revelation about the intelligibility of nature. A next degree may be found in a physicist who is a Catholic, because he has the certainty provided by the explicit teaching of the Church's Magisterium in that matter. There is a highest degree, which belongs to a physicist who is a Catholic and deliberately wishes to follow the advice given in 1 Cor 10:31.

The second parameter covers the range of the object of a physicist's professional actions: if the goal of the actions consists in producing some technological product, practical factors of all sort are relevant so that the aiming at knowledge for its own sake is secondary. Particularly, it seems reasonable to make models adapted to the practical goal and perform, to this end, simplifications and abstractions. Epistemological criteria are less relevant and, therefore, the lack of harmony of a physicist's mental world is less deep. On the other hand, a physicist whose professional actions concern fundamental questions, for instance elementary particles, cosmology and the like, where technological advance is merely a byproduct, the aiming at knowledge for its own sake has priority. In such cases, models as well as abstractions and simplifications have a direct epistemological bearing. Consequently, the lack of harmony of a physicist's mental world can be deep.

\footnotetext{
${ }^{3}$ Cf. First Vatican Council, Dogmatic Constitution Dei Filius, Dz 1785, 1806.
} 
Taking all together, this moral assessment calls for an amendment of Physics, first from the point of view of Natural Realism and then backed up by Christian revelation. This has already been insinuated in the mentioned earlier article and should happen by an "internal reform" of Physics with the goal of converting the contrast or opposition of epistemological climates into a harmonious relationship. On the other hand, Catholic Theology is not a candidate for internal reforms, because its growth is essentially homogeneous and thus keeps its identity, while physics has undergone well known essential changes of paradigms.

The question of how to bring about such an internal reform of Physics, is quite another thing. It it outside the scope of this article, but it has already become clear that a proper amendment is not a merely superficial re-arrangement and cannot be achieved neither by a single person nor in a short time. But it might be helpful to have a closer look at the two epistemological climates, in order to ascertain better when it comes to suggest the first steps of an amendment.

\section{THE EPISTEMOLOGICAL CLIMATE OF NATURAL REALISM}

The German philosopher Nicolai Hartmann was affiliated, in the beginning of his academic career, to the New-Kantianism of the Marburg School. Later he left this stance and embraced what he called 'natural realism'. However, he did not completely abandon the Kantian view: in his view of the process of knowing, he continued attributing a certain priority to the person's consciousness before reality. If we disregard this element, we arrive, by and large, at a sort of realism similar to that which Aristotle had embraced. In any case, Hartmann has impressive words to express how strongly reality shapes the human cognitive capacity. The gentle power of reality makes obsolete any attempt of overriding by a purely theoretical argument what has been perceived. The knowing subject cannot escape reality. ${ }^{4}$

Natural Realism is the only philosophical position that is not preceded by any other position. Additionally, any other philosophical position is preceded

\footnotetext{
${ }^{4}$ Nicolai Hartmann, Grundzüge einer Metaphysik der Erkenntnis (Berlin, 1965), Chapter 13 'Natürlicher Realismus', p. 33-134 and p. 134-135.
} 
by Natural Realism which cannot be completely left. A human person acquires that position from his earliest childhood on by just living in a normal social and cognitive environment and recognizes that other persons are in the same situation. Moreover, it contains what Thomas Aquinas and others would call evident insights or insights per se notae, such as the principle of noncontradiction (nothing can be and not be, at the same time) or the principle that the whole is more comprehensive than its parts, in the realm of theoretical knowledge. In the realm of moral knowledge, the principle that good is to be done and evil to be avoided and that killing the innocent is intrinsically evil.

\section{THE EPISTEMOLOGICAL CLIMATE OF PHYSICS}

While the individual methods, standards and rules of the art in Physics develop, the spirit by which they are inspired is practically constant. This is mostly due to the presence of Mathematics in Physics. According to most historians of science, the mathematization of physics has been the greatest single factor constituent of the Scientific Revolution of the $17^{\text {th }}$ century. ${ }^{5}$ This has made the modern natural science named 'physics', which has little in common with the philosophy of nature inherited from antiquity. The importance and, at the same time, the problematic character of that revolution can be better appreciated by considering that

a) While physics refers to individual and changing material realities, mathematics is based on abstract and invariable principles. The foundation of present-day mathematics are axioms. "The role of intuition and observation is explicitly limited to motivation and is heuristic. Once the axioms have been formulated, intuition and observation are banished. They are not part of mathematics."

b) Physicists have only a practical knowledge of how mathematics and reality are connected, namely by performing experiments. Thus, the link between the two bodies of knowledge - mathematics and experience - is located within the cognitive and practical capacities of the experimenter-theoretician. Yet, it is unknown, whether there is such a link in reality itself. The answer to that question would be based on experience and purely theoretical.

\footnotetext{
${ }^{5}$ Eduard J. DiJksterhuis, The Mechanization of the World Picture (Oxford: Oxford University Press, 1961), passim.

${ }^{6}$ Steward ShapIro, Thinking about Mathematics. The Philosophy of Mathematics (Oxford: Oxford University Press, 2000), p. 151.
} 
In our context, we need only to take into account that the lack of knowledge about the relationship between things mathematical and things material has brought about the hypothetical-deductive method of physics. That method has generated in Physics, over the centuries, a typical epistemological climate, which is pinpointed by the conviction of physicists that nature is, by and large, unintelligible. Therefore, it is necessary, to make models and hypotheses, test them by experiments and, if convenient, improve the models and hypotheses by a process of trial and error. If the relationship between things mathematical and things material were known, it would be possible to write down mathematical laws of nature after just having thought about them.

The conviction that nature is unintelligible (at least for scientific purposes) forces the physicist to produce pictures of nature by himself. The following three quotations paradigmatically tell about how physicists themselves describe what they are doing and think of what they do. The first quotation stems from Heinrich Hertz. Though written more than 100 years ago, these words continue being a guideline of a physicist's professional work:

"The most direct, and in a sense the most important, problem which our conscious knowledge of nature should enable us to solve is the anticipation of future events, so that we may arrange our present affairs in accordance with such anticipation. [...] In endeavouring thus to draw inferences as to the future from the past, we always adopt the following process. We form for ourselves images [innere Scheinbilder] or symbols of external objects; and the form which we give them is such that the necessary consequents of the images in thought are always the images of the necessary consequents in nature of the things pictured.

[...] The images which we here speak of are our conceptions of things. With the things themselves they are in conformity in one important respect, namely, in satisfying the above-mentioned, requirement. For our purpose it is not necessary that they should be in conformity with the things in any other respect whatever. As a matter of fact, we do not know, nor have we any means of knowing, whether our conceptions of things are in conformity with them in any other than this one fundamental respect. [...] The images which we may form of things are not determined without ambiguity by the requirement that the consequents of the images must be the images of the consequents."7

${ }^{7}$ HeInRICh Hertz, The Principles of Mechanics Presented in a New Form (London: McMillan, 1899), Introduction. 
The second quotation is by Stephen Hawking/Leonid Mlodinow and sums up in a few concise words the ideas of Hertz and, at the same time, pinpoints the mindset of the vast majority of present day physicists:

"There is no picture- or theory-independent concept of reality. Instead we adopt a view that we call model-dependent realism: the idea that a physical theory or world picture is a model (generally of a mathematical nature) and a set of rules that connect the elements of the model to observations."

"According to the idea of model-dependent realism [...] our brains interpret the input from our sensory organs by making a model of the outside world. We form mental concepts of our home, trees, other people, the electricity that flows from wall sockets, atoms, molecules, and other universes. These mental concepts are the only reality we can know. There is no modelindependent test of reality. It follows that a well-constructed model creates a reality of its own."

"Your reality depends on the model you employ."

Another sample of the same mindset is Karl Popper's well-known idea of theory laden experience:

"Even the careful and sober testing of our ideas by experience is in its turn inspired by ideas: experiment is planned action in which every step is guided by theory. We do not stumble upon our experiences, nor do we let them flow over us like a stream. Rather, we have to be active: we have to 'make' our experiences. It is we who always formulate the questions to be put to nature; it is we who try again and again to put these questions so as to elicit a clear-cut 'yes' or 'no' (for nature does not give an answer unless pressed for it). And in the end, it is again we who give the answer, it is we ourselves who, after severe scrutiny, decide upon the answer to the question we put to nature."

In conclusion, we might qualify the epistemological setting of Physics as broadly Kantian, as can be seen from the following key quotations from the Critique of pure reason:

"Although all our knowledge begins with experience, that doesn't mean that it all comes from experience." 10 For "[t]he order and regularity in appearances, which we call Nature, are put there by ourselves. We could never

\footnotetext{
${ }^{8}$ Stephen Hawking, LeOnid Mlodinow, The Grand Design - A New Explanation of the Universe (New York: Bantam Books, 2010), p. 42, 172 and 175, respectively.

${ }^{9}$ KARL R. POPPER, The Logic of Scientific Discovery (London: Routledge Classic, 2002), n. 85 .

${ }^{10}$ IMMANUEl KANT, Critique of pure Reason (2. edition, 1787), www.earlymoderntexts. com/assets/pdfs/kant1781part1.pdf, margin number 1.
} 
find them in appearances if it weren't that we, or the nature of our mind, had first put them there."11

And a little bit later, another reference to the "copernican turn":

"Even though it might seem counterintuitive, the understanding isn't a mere power of formulating rules through comparison of appearances; it is itself the lawgiver of Nature. It's only through the understanding that Nature exists at all! [...]. Nature is the synthetic unity of the manifold of appearances according to rules. And appearances can't exist outside us-they exist only in our sensibility. Thus, Nature [...] is possible only in the unity of self-awareness."

The intellectual dependence from Kant is obvious, even though only a minority of physicists might be aware of that philosophical affiliation.

As is well known, the method of making theoretical hypotheses and testing them experimentally is highly successful. This word 'successful' indicates that a new category comes into play, which is not identical to 'truth'. Roughly speaking, it goes like this: based on his experiments, the experimenter states a harmony or lack of harmony (not: equality or lack of it) between real physical processes and their mathematical representation. The harmony is measured quantitatively and is, according to all experience, gradual (between 0 and $100 \%$, excluding the limits). If the harmony surpasses a threshold determined by convention, one speaks of 'success'. That is not reducible to the pair of concepts true - false.

'Nevertheless, the category success is not completely alien to the categories of true and false, for the success is a true success. (Otherwise, there would be no technology at all, but chaos.) Therefore, the success contributes to the moral goodness of a physicist's professional actions. But again, success - or in Hertz's terminology, the possibility of predicting physical processes - is not identical with truth. The considerable loss of truth has led, altogether, to a deep skepticism that is hiding behind the sharp and brilliant rationality of mathematics. Since centuries, there exists an increasing tension between the investigation of nature such as it is (truth) and the interest in practical applications of that investigation (success). The claim that this gap has become one of the most characteristic features of the Western technological civilization, does not seem to be an exaggeration.

The problematic character of this situation becomes even clearer by considering that it is rather the knowledge of truth and not only the ability of

\footnotetext{
${ }^{11}$ IMMANUEL KANT, Critique of pure Reason (first edition, 1781), www.earlymoderntexts. com/assets/pdfs/kant1781part1.pdf, marginal number A125. The following quotation is from marginal number A127.
} 
practicing some successful procedures which leads, in the long run, to a better technology. In other words, one could distinguish between a physics made according to the mindset of engineers (using models, simplifications, with the aim of achieving a working theory with technical applications) and a physics made according to the mindset of philosophers, who are less interested in technology, than in the truth. Thus, on the long run, it pays off to take into account a philosophy-minded physics.

Given the present-day diversity of philosophical schools, a first distinction is helpful as to which sort of philosophy would do it best. On the one hand, in physics, such as it has historically developed, the two bodies of knowledge - experiential and mathematical - are united in the experimenter-theoretician only. On the other hand, it is unknown whether the corresponding realities - individual material things and abstract mathematical objects - are united in these very same material things. The answer to the question for the best suited philosophy proceeds by using a classical distinction: an Aristoteliantype philosophy would see both elements united in the material things (universale in re), a Kantian-type philosophy would tend to deny precisely that (universale post rem), as well as a Platonist-type philosophy (universale ante rem). Thence, the Aristotelian-type philosophy is the only candidate for possibly giving an account of the union of both in reality itself.

\section{THE PHILOSOPHICAL PERSPECTIVE OF THE AMENDMENT: INTELLIGIBILITY}

The opposition of epistemological climates is certainly a shortcoming, as a personal as well as a common "public" intellectual situation. Therefore, it is reasonable trying to dissolve it. It seems that such a dissolution requires getting rid of certain reductionisms, which are connected with experiments and do not correspond to anything in nature. Obviously, here becomes relevant the experimenter's creativity. Among these reductionisms are the choice of an experimental object and an experimental apparatus and the prevalent attribution of the experimental result to the object alone. It is clear from the very outset that such a dissolution requires comprehensive considerations of many sorts and can hardly be realized neither by a single person nor in a short time.

In any case, the amendment of the morality of a physicist's professional actions depends on the degree to which the opposition between the epistemological climate of Physics and the one of Natural Realism can be dissolved. For 
that end, it could be helpful to have a closer look at the present epistemological situation of physics which can be characterised by the following four contrasts:

Physics has always been a science based on experience. Experiments, too, are embedded in experience. On the other hand, the philosophical mainstream ever since Descartes claims that experience is not a sufficient source of knowledge or not a source of knowledge at all.

Experiments are used as a means to obtain information about an object. But at the same time, experiments are viewed as a perturbation of that object. This makes it difficult, if not impossible, to obtain knowledge about the unperturbed object.

In physics, things mathematical are connected with things material. However, at the same time, the dominating axiomatic construction of mathematics suggests that it has little or nothing to do with the material world.

It is unknown why and how certain mathematical objects relate to material things. Nevertheless, physics has found itself for centuries in an ever increasing mathematization. This process makes physics flee into a surrogate rationality and alienate itself more and more from natural realism.

After that, it might be easier to examine the problem itself, i.e. the question 'why exists mathematics in physics'. In fact, every year appears a considerable amount of publications on precisely that topic, although very few in the spirit of Natural Realism. Thus, so far is little hope for an amendment of the morality of a physicist's professional actions.

The solution of the problem 'why exists mathematics in physics?' should neither use mathematics nor simply dismiss physics as a whole such as it has historically developed. The former is necessary for the sake of logical validity of the solution, and the latter takes into account that the success of physics is true and not fictitious, even though success is different from truth. This situation of as well - as seems to be the main difficulty of the problem.

The question of "why exists mathematics in physics" is not identical with the actual derivation of mathematical theories of physical processes from experience. But it is to be expected that the answer to the question 'why' also provides information about that derivation. Conversely, such derivation would largely, if not completely, answer the question 'why'. However, it is clear from the outset that a derivation cannot yield the already known successful physical-mathematical theories. For then the reductionisms would have to be deduced despite the fact that they have been excluded from the outset. That is impossible.

Such a derivation, assuming its existence, would provide a "more comprehensive" mathematical theory. Given such a theory, it should be expected that 
the hitherto known successful physical-mathematical theories would somehow appear as a "projection" or as a "special case", with the abovementioned reductionisms having to be reintroduced. It is obvious that such a derivation would prove a high degree of intelligibility of nature. This would at least greatly reduce the opposition of epistemological climates, which would have corresponding consequences for the morality of a physicist's professional actions.

But it is certainly wiser to refrain from further speculation and to focus on what lies within reach. The systematic avoidance of abstractions, models and simplifications from the very outset and the working out of the consequences is, in fact, something that can be tackled immediately. It possibly provides a kind of control of the losses due to the reductionisms in present-day physics. Whatever the details of that approach, it should be based, from the outset, on a high cognitive value of experience and thus on Natural Realism. ${ }^{12}$

Even such a control would be a certain proof of the intelligibility of nature and would reduce the said opposition of epistemological climates. It would confirm that present-day physics is truly successful, on the one hand but, on the other hand, the success is driven away from truth by the reductionisms. This limiting qualification of success radically changes the epistemological situation of a physicist. He now knows that the current epistemological climate of physics is not "the last word," and that abstractions, models, and simplifications may be useful and successful, but always come at the price of loss of knowledge.

\section{THE CHRISTIAN PERSPECTIVE \\ OF THE AMENDMENT: 1 Cor 10:31}

The outcome of the philosophical perspective makes it clear for theologians as well as for non-believers that only a Physics which is equipped that control can be an adequate partner for the dialogue with Theology. This makes us turn th the Christian perspective of amendment. There is no need to stress once again that the only specific contribution of Christianity for solving the problem is precisely that Christian revelation powerfully backs up

\footnotetext{
12 An example of how to settle the approach and what sort of results can be expected is offered in: Rudolf LARENZ, What Can Thomistic Philosophy of Nature Contribute to Physics?, Societal Studies 2013, 5(2): 481-499, and IDEM, Substance and Dynamics: Two Elements of Aristotelian-Thomistic Philosophy of Nature in the Foundation of Mathematics in Physics, Studia Gilsoniana 2017, 6(3): 451-483.
} 
the conviction of the world's intelligibility. This certainly encourages a Christian to face the problem and, if it is within his reach, to try to tackle it with the intellectual means available to everybody, whether baptized or unbaptized. It will help a Christian to continue his investigation even in moments when no progress is in sight.

The reserve of Christianity with respect to particularities of the solution is the reason why the pertinent indications of the Magisterium are very general and, at the same time, very fundamental. An example for this is the appeal, that John Paul II addresses to scientists in his encyclical Fides et ratio:

"Finally, I cannot fail to address a word to scientists, whose research offers an ever greater knowledge of the universe as a whole and of the incredibly rich array of its component parts, animate and inanimate, with their complex atomic and molecular structures. So far has science come, especially in this century, that its achievements never cease to amaze us. In expressing my admiration and in offering encouragement to these brave pioneers of scientific research [...]. I would urge them to continue their efforts without ever abandoning the sapiential horizon within which scientific and technological achievements are wedded to the philosophical and ethical values which are the distinctive and indelible mark of the human person." 13

The only word in this passage marked as a key word is 'sapiential'. Natural sciences, as well as human knowledge in general, should strive to assimilate the sapiential horizon given by reality itself rather than pretend to constitute themselves as a sapiential horizon. This is true irrespective of whether the human persons implied are believers or not. Obviously, this is nothing but a sign of the prioritarian position of Natural Realism.

Christians possess the explicit certainty that all reality is not only the immediate root of the sapiential horizon, but that the horizon is created by God. Thus, a Christian knows that everything without exception bears a relationship to the Creator. Therefore, (the continuously itself potentiating) technology is not a surrogate for God, but a gift of God, as is given to understand by a text from Gaudium et spes:

"Today, especially with the help of science and technology, [man] has extended his mastery over nearly the whole of nature and continues to do so. Hence many benefits once looked for, especially from heavenly powers, man has now enterprisingly procured for himself." (GS 33) "[...] This human activity accords with God's will. For man, created to God's image, received

\footnotetext{
13 IOANNES PAULUS II, Encyclical Fides et ratio, 106,2.
} 
a mandate to subject to himself the earth and all it contains, and to govern the world with justice and holiness; a mandate to relate himself and the totality of things to Him Who was to be acknowledged as the Lord and Creator of all. Thus, by the subjection of all things to man, the name of God would be wonderful in all the earth. [...] Thus, far from thinking that works produced by man's own talent and energy are in opposition to God's power, and that the rational creature exists as a kind of rival to the Creator, Christians are convinced that the triumphs of the human race are a sign of God's grace and the flowering of His own mysterious design" (GS 34). ${ }^{14}$

The admonition of St. Paul: "Whether you eat or drink or do anything else, do everything to glorify God!" (1 Cor 10:31) expresses the same idea, without referring to any special human achievements. His words refer to both the intention of the actor and to what he actually does. In addition, they implicitly include a harmony between intention and action, or rather an invitation to reconcile or hold action in keeping with the intention. This harmony between thinking and willing, on the one hand, and acting, on the other, does not come about automatically, as the general experience teaches and Jesus gives to understand (Matth. 23:2).

1 Cor 10:31 together with the just mentioned explanations makes it clear that the invitation of Fides et ratio to internalize a sapiential horizon also belongs to the glory of God. In the case of the professional work of physicists, they stand before the task to integrate the epistemological climate of Physics into a sapiential horizon. This in turn means to make the epistemological climate of Natural Realism part of the bases of Physics. Only then the internal practical-theoretical contradiction disappears, that a physicist is forced by his science to understand his professional actions as if they were guided by the view of nature as unintelligible, while he is, in the light of his Natural Realism convinced that nature is intelligible. This conviction is confirmed by Christian revelation.

\section{CONCLUSION}

The contrast between the epistemological climate prevailing in physics and that of Natural Realism makes a physicist deny practically, day in and day out, by his professional action, of which he is convinced theoretically. It is

\footnotetext{
${ }^{14}$ Second Vatican Council, Pastoral Constitution Gaudium et spes, 33, 34.
} 
a sign that the Kantian "copernican turn" is not able to leave Natural Realism. This denial allows for different degrees, depending on how his world view is shaped by natural realism or additionally by the Christian faith. Moreover, the depth of denial depends on the proximity of a physicist's professional work to ultimate questions. This opposition diminishes the moral goodness of a physicist's actions, but never transforms the morally good professional actions of a physicist into something morally evil. Therefore, it is possible to fulfill the request in 1 Cor 10:31, but not fully. It should be repeated that the emphasis on the opposition of epistemological climates and the subsequent discourse is almost completely absent in the academic dispute.

The situation just described began with the Scientific Revolution of the $17^{\text {th }}$ century and has deepened ever since. Over the centuries, the success of natural sciences has led to a scientific-technological civilization accompanied by a specific intellectual climate. It also means that the practical implications of knowledge become more important than philosophy and religion. Accordingly, the power of philosophy and religion to inspire action and life, is valued less.

In contrast, the findings resumed in the first paragraph of this section suggest that the philosophical problem of the opposition of epistemological climates should be recognized as such and its solution tackled. Christianity underpins the conviction of the intelligibility of nature, thus encouraging a fundamental problem of physics (things mathematical - things material) to be tackled with the conceptual tools of Natural Realism. To the extent that this encouragement is put into practice, we are undoubtedly standing before a powerful element of inculturation of Christianity into the existing scientific-technological civilization. That is, the word 'inculturation' is understood here primarily in the direction 'from Christianity to culture' and not vice versa, as in some historical cases. In this sense, it is not a part, but a flanking aid of the new Evangelization.

\section{BIBLIOGRAPHY}

DiJKsterhuis, Eduard J. The Mechanization of the World Picture. Oxford: Oxford University Press, 1961.

FIRST VATICAN CounCIL. Dogmatic Constitution Dei Filius.

HaRtMann, NicolaI. Grundzüge einer Metaphysik der Erkenntnis. Berlin: Walter de Gruyter, 1965. The passages cited in the text are available online under https://books.google.fi/book$\mathrm{s}$ ?id=YaEhAAAAQBAJ\&hl=fi\&source=gbs_book_other_versions; click 'Realistische Theorien'. Retrieved 10.06.2019. 
Hawking, Stephen, Mlodinow, Leonid. The Grand Design - A New Explanation of the Universe. New York: Bantam Books (Random House), 2010.

Hertz, HeInRICH. The Principles of Mechanics Presented in a New Form. London: Macmillan \& Co. Ltd., 1899. Online: https://archive.org/details/principles ofmech00hertuoft/page/xxviii. Retrieved 11.06.2019.

IOANNES PAUlus II. Encyclical Fides et ratio (1998).

Kant, IMmANUEL. Critique of pure Reason (first edition (1781) and second edition (1787)), www.earlymoderntexts.com/authors/kant/; ed. Jonathan Bennett. Retrieved 11.06.2019.

LARENZ, RUdOLF. Physics - 'Alienation from' instead of 'Orientation towards' the Creator? Roczniki Teologii Moralnej [Lublin] 2011, 3(58): 5-37. Online: http:// cejsh.icm.edu. pl/cejsh/element/bwmeta1.element.desklight-92c8dcdd-f35a-44d5-818d-0a757f71d714. Retrieved 11.06.2019.

Larenz, Rudolf. What Can Thomistic Philosophy of Nature Contribute to Physics? Societal Studies [Vilnius] 2013, 5(2): 481-499. Online: https://www. mruni.eu/en/mokslo_darbai/ sms/archyvas/dwn.php?id=346 139, or www.ceeol.com/aspx/issuedetails.aspx?issueid=a32d 97e6-e73e-4341-6a52-beca82334a4e. Retrieved 11.06.2019.

LARENZ, Rudolf. Substance and Dynamics: Two Elements of Aristotelian-Thomistic Philosophy of Nature in the Foundation of Mathematics in Physics. Studia Gilsoniana 2017, 6(3): 451-483. Online www.gilsonsociety.com/files/ 451-483-Larenz.pdf. Retrieved 11.06.2019.

A shorter previous version appeared in Polish in: $O$ metafizyce Arystotelesa. U podstaw filozofowania realistycznego. Zadania wspótczesnej metafizyki. Lublin: Polskie Towarzystwo Tomasza z Akwinu, Lublin, 2017, p. 191-220. (Substancja i dynamika. Dwa elementy arystotelesowsko-tomistycznej filozofii przyrody jako podstawa matematyki w fizyce).

POPPER, KARL, R. The Logic of Scientific Discovery. London: Routledge (Routledge Classics), 2002. Online: https://archive.org/details/PopperLogicSci entificDiscovery/page/xx. For the particular quotation in the text, "xx" should be replaced by "n307". Retrieved 11.06.2019.

Shapiro, SteWARD. Thinking about Mathematics. The Philosophy of Mathematics. Oxford: Oxford University Press, 2000.

SeCond Vatican Council. Pastoral Constitution Gaudium et spes (1965).

\section{O ZMIANIE MORALNOŚCI PROFESJONALNYCH DZIAŁAŃ FIZYKA NOWY ELEMENT INKULTURACJI CHRZEŚCIJAŃSTWA W CYWILIZACJE NAUKOWO-TECHNOLOGICZNA}

St res z c z e n i e

Fizycy są zobowiązani, zgodnie z ustalonymi metodami i standardami fizyki, do myślenia i działania w ramach epistemologicznych, na co głęboki wpływ miał I. Kant. Klimat epistemologiczny, w którym się znajdują, sprzeciwia się epistemologicznemu klimatowi realizmu naturalnego, a tym samym epistemologicznemu klimatowi Objawienia chrześcijańskiego, kiedy mówi ono o naszym świecie. Ten kontrast niszczy wewnętrzną harmonię świata umysłowego każdego fizyka w takim stopniu, w jakim zależy on od jego ogólnego sposobu myślenia, a także od jego pracy zawodowej. Sytuacja ta trwa od czasów rewolucji naukowej XVII wieku, tak że wcześniejsza cywilizacja odznaczająca się realizmem i duchem chrześcijańskim została w zasadzie zastąpiona przez cywilizację naukowo-technologiczną. 
Historyczny rozwój fizyki doprowadził do sytuacji, w której praca zawodowa fizyków, z jej niewątpliwymi sukcesami i wkładem w postęp, prowadzi wraz z moralnie godziwym przedmiotem do dwóch złych skutków. Pierwszym złym skutkiem jest współistnienie w umyśle fizyka dwóch przeciwnych epistemologicznych klimatów, co niszczy wewnętrzną harmonię jego świata umysłowego. Natychmiast pociąga to za sobą drugi zły skutek w sytuacji, gdy fizyk, aby być zawodowo konkurencyjnym, jest zmuszony do przestrzegania metod i standardów fizyki, tak jak teraz. W ten sposób przyczynia się do braku harmonii w jego umysłowym świecie i poprzez swój drobny wkład utrwala ducha tych metod $i$ standardów. W trudniejszej sytuacji jest fizyk, który jest chrześcijaninem i chce wykonywać swoją pracę zawodową na chwałę Boga (por. 1 Kor 10,31). W obu przypadkach fizyk, wykonując swoją pracę zawodowa, w praktyce zaprzecza o tym, o czym jest $w$ teorii przekonany, a mianowicie o realizmie naturalnym, a dodatkowo, w przypadku chrześcijanina także o tym, że chrześcijańskie Objawienie mówi o naszym świecie w duchu naturalnego realizmu.

Wszystko to nie jest nieznane, ale mimo to jest praktycznie pomijane w dyskursie akademickim. W związku z tym, celem tego artykułu jest zwrócenie uwagi na powyższą kwestię, a następnie wskazanie kilku sposobów dokładniejszego zbadania kontrastu epistemologicznych klimatów, ponieważ fizyka jest częściowo kształtowana przez eksperymenty, a jej historyczny rozwój jest również częściowo warunkowy. Dlatego możliwe jest osiąnięcie lepszej harmonii epistemologicznych klimatów fizyki i realizmu naturalnego. Artykuł sugeruje także pewne idee w tym zakresie. Jeśli okażą się one owocne, przyczynią się do inkulturacji chrześcijaństwa w naszej cywilizacji naukowo-technicznej. Innymi słowy stanowiłoby to wsparcie dla nowej ewangelizacji.

Słowa kluczowe: inkulturacja chrześcijaństwa; moralność czynów o podwójnym skutku; fizyka; cywilizacja naukowo-technologiczna; realizm naturalny; objawienie chrześcijańskie; klimaty epistemologiczne. 